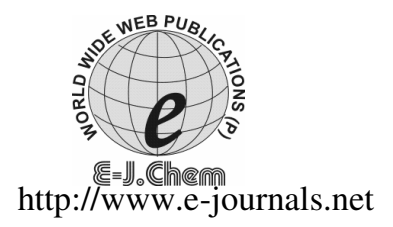

ISSN: 0973-4945; CODEN ECJHAO

E-Journal of Chemistry 2011, 8(2), 753-761

\title{
RP-HPLC Determination of Three Anti-Hyperlipidemic Drugs in Spiked Human Plasma and in Dosage Forms
}

\author{
OLA. M. ABDALLAH \\ Analytical Chemistry Department, Faculty of Pharmacy \\ October University for Modern Sciences and Arts (MSA) \\ El- Wahat Road, $6^{\text {th }}$ October City, Egypt \\ olamody@yahoo.com
}

Received 19 June 2010; Accepted 2 September 2010

\begin{abstract}
Sensitive, simple and accurate high performance liquid chromatographic (HPLC) methods for the determination of atorvastatin (AT), fluvastatin (FL) and pravastatin (PV) have been developed. The proposed methods involve the use of a $150 \mathrm{~mm} 4.6 \mathrm{~mm}$ Zorbax Extend-C18 column ( $5 \mu \mathrm{m}$ particle size) and different chromatographic conditions for the separation of the three statins. Linearity range was $5-40,5-30$ and $10-60 \mu \mathrm{g} \mathrm{mL}^{-1}$ for AT, FL and PV respectively. The developed methods proved to be successful in the determination of all studied drugs in spiked human plasma samples.
\end{abstract}

Keywords: Atorvastatin, Fluvastatin, Pravastatin, HPLC

\section{Introduction}

Statins lower cholesterol by inhibiting the synthesis of mevalonic acid, which is a precursor in cholesterol synthesis. Dropping mevalonic acid levels triggers the expression of more low density lipoprotein (LDL) receptors in the liver, which then removes LDL from blood stream ${ }^{1}$.

Atorvastatin calcium is chemically known as, $\left[\mathrm{R}-\left(\mathrm{R}^{*}, \mathrm{R}^{*}\right)\right]-2-(4-f l u o r o p h e n y l)-\beta, \delta-$ dihydroxy-5-(1-methylethyl)-3-phenyl-4-[(phenylamino)carbonyl]- $1 H$-pyrrole-1-heptanoic acid, calcium salt (2:1) trihydrate. Published analytical methods for the quantitative determination of atorvastatin in pharmaceutical formulations and human body fluids include, spectrophotometry $y^{2-4}$, colorimetry via ion pair complexes ${ }^{5}$, FT-Raman spectroscopy ${ }^{6}$, HPLC methods, with UV detection ${ }^{7-11}$ and tandem mass spectrometry detection ${ }^{12-14}$, LC-MS $^{15}$ and $^{16}$, HPTLC $^{17,18}$, voltammetric ${ }^{19}$, capillary electrophoresis ${ }^{20}$. Other reported methods for the determination of atorvastatin depend on assay of HMG-CoA reductase inhibition like that developed by Shum et al $^{21}$. 
Few methods have been reported for the determination of fluvastatin, (3R,5S,6E)-7[3-(4-fluorophenyl)-1-(propan-2-yl)-1 $H$-indol-2-yl]-3,5-dihydroxyhept-6-enoic acid including spectrophotometry ${ }^{22}$, HPLC methods with ultraviolet (UV) detection ${ }^{23}$, fluorometric detection $^{24,25}$ and tandem mass spectrometry detection ${ }^{14}, \mathrm{GC}^{-\mathrm{MS}^{26}}$, voltammetric $^{27}$ and capillary electrophoresis ${ }^{28}$. Several methods have been developed for the estimation of pravastatin in dosage forms and biological fluids including, HPLC methods, with UV detection $^{29-33}$ and tandem mass spectrometry detection ${ }^{14,34}$, LC-MS ${ }^{35,36},{ }^{1} \mathrm{H} \mathrm{NMR}^{37}$, voltammetric ${ }^{38}$ and polarographic ${ }^{39}$.

This work describes simple, fast and sensitive HPLC methods for the determination of atorvastatin, fluvastatin and pravastatin in bulk form, in pharmaceutical formulations and in spiked human plasma without sample pretreatment or time-consuming extraction prior to analysis.

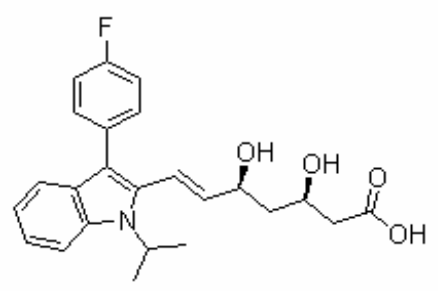

Fluvastatin

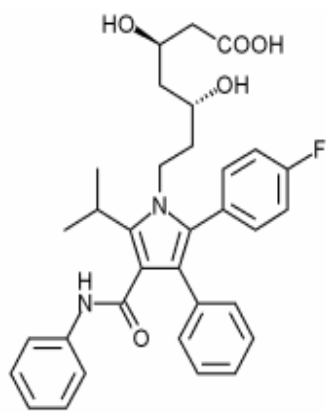

Atorvastatin<smiles>CCC(C)C(=O)O[C@H]1CC(O)C=C2C=C[C@H](C)[C@H](CC[C@H](O)CC(O)CC(=O)O)[C@]21C</smiles>

Pravastatin

\section{Scheme 1}

\section{Experimental}

Agilent 1200 series isocratic quaternary pump HPLC instrument connected to 1200 multiple wavelength UV detector was used. Separation was performed on 150x4.6 mm Zorbax Extend-C18 column $5 \mu \mathrm{m}$ particle size. Chromatographic peaks were electronically integrated and recorded using Chemstation software (Germany). $\mathrm{pH} / \mathrm{mv}$ Meter with double junction glass electrode (Fisher, USA) and Hamilton syringes $25 \mu \mathrm{L}$ were used

\section{Reagent and chemicals}

HPLC grade acetonitrile was purchased from Fisher scientific (UK). Phosphoric acid and potassium dihydrogen phosphate were purchased from Sigma- Aldrich Chemie (Germany). Demineralized water was further purified by filtering through a $0.45 \mu \mathrm{m}$ Millipore filter (Gelman, Germany).

\section{Materials}

Atorvastatin calcium, fluvastatin sodium, pravastatin sodium, pyridoxine hydrochloride (PR) and ipubrofen (IB) authentic powders were kindly supplied by EPICO, Novartis Pharma, HI Pharm pharmaceuticals and Memphis Co., respectively. Plasma samples were purchased from the local hospital blood bank.

\section{Pharmaceutical preparations}

Ator $^{\circledR}$ tablets produced by EPICO, batch No. 083127, claimed to contain $20 \mathrm{mg}$ AT. Lescol $^{\circledR}$ XL tablets packed by Novartis Pharma, batch No. 149/B5589, claimed to contain $84.24 \mathrm{mg}$ fluvastatin sodium which corresponds to $80 \mathrm{mg}$ fluvastatin free acid. Cholestate ${ }^{\circledR}$ film coated tablets product of HI Pharm pharmaceuticals, batch No. 1012209, claimed to contain $10.5 \mathrm{mg}$ pravastatin. 


\section{Standard drug solutions \\ Solutions of atorvastatin}

Accurately weighed amounts of standard AT were dissolved in $100 \mathrm{~mL}$ volumetric flask using methanol and diluted to volume with the same solvent to get 0.1 or $1 \mathrm{mg} \mathrm{mL}^{-1}$ solutions.

\section{Solutions of fluvastatin}

Accurately weighed amounts of standard FL were dissolved in $100 \mathrm{~mL}$ volumetric flask using acetonitrile - water mixture (50:50) and diluted to volume with the same solvent to get 0.1 or $1 \mathrm{mg} \mathrm{mL}^{-1}$ solutions.

\section{Solutions of pravastatin}

Accurately weighed amounts of standard PV were dissolved in $100 \mathrm{~mL}$ volumetric flask using acetonitrile - water mixture (50:50) and diluted to volume with the same solvent to get 0.1 or $2 \mathrm{mg} \mathrm{Ml}^{-1}$ solutions.

\section{Solutions of pyridoxine $\mathrm{HCl}$ (internal standard)}

Accurately weighed amounts of standard PR were dissolved in $100 \mathrm{~mL}$ volumetric flask using methanol and diluted to volume with the same solvent to get 0.5 or $10 \mathrm{mg} \mathrm{mL}^{-1}$ solutions.

\section{Solutions of ipubrofen (internal standard)}

Accurately weighed amounts of standard IB were dissolved in $100 \mathrm{~mL}$ volumetric flask using methanol and diluted to volume with the same solvent to yield 1 or $10 \mathrm{mg} \mathrm{mL}^{-1}$ solutions.

\section{Calibration}

\section{Atorvastatin}

Aliquots of the standard drug solution $\left(0.1 \mathrm{mg} \mathrm{mL}^{-1}\right)$ in methanol equivalent to $0.04-0.4 \mathrm{mg}$ AT were transferred to a series of $10 \mathrm{~mL}$ volumetric flasks; $1 \mathrm{~mL}$ of pyridoxine internal standard solution $\left(0.5 \mathrm{mg} \mathrm{mL}^{-1}\right)$ was added to each flask then diluted to volume using the mobile phase consisting of acetonitile-50 $\mathrm{mM} \mathrm{KH}_{2} \mathrm{PO} 4(60: 40 \mathrm{v} / \mathrm{v})$ adjusted to $\mathrm{pH} 3.5$ by phosphoric acid.

\section{Fluvastatin}

Aliquots of the standard drug solution $\left(0.1 \mathrm{mg} \mathrm{mL}^{-1}\right)$ in acetonitrile - water mixture (50:50) equivalent to $0.05-0.3 \mathrm{mg}$ FL were transferred to a series of $10 \mathrm{~mL}$ volumetric flasks; $1 \mathrm{~mL}$ of pyridoxine internal standard solution $\left(0.5 \mathrm{mg} \mathrm{mL}^{-1}\right)$ was added to each flask then diluted to volume using the mobile phase consisting of acetonitile- $50 \mathrm{mM} \mathrm{KH}_{2} \mathrm{PO} 4(60: 40 \mathrm{v} / \mathrm{v})$ adjusted to $\mathrm{pH} 3.5$ by phosphoric acid.

\section{Pravastatin}

Aliquots of the standard drug solution $\left(0.1 \mathrm{mg} \mathrm{mL}^{-1}\right)$ in methanol equivalent to $0.04-0.4 \mathrm{mg} \mathrm{PV}$ were transferred to a series of $10 \mathrm{~mL}$ volumetric flasks; $1 \mathrm{~mL}$ of ipubrofen internal standard solution $\left(1 \mathrm{mg} \mathrm{mL}^{-1}\right)$ was added to each flask then diluted to volume using the mobile phase consisting of acetonitile-50 $\mathrm{mM} \mathrm{K \textrm {K } _ { 2 }} \mathrm{PO} 4(40: 60 \mathrm{v} / \mathrm{v})$ adjusted to $\mathrm{pH} 3.5$ by phosphoric acid.

Triplicate $20 \mu \mathrm{L}$ of each drug solution were injected into the liquid chromatograph using the following chromatographic conditions: Detector wavelength: $210 \mathrm{~nm}$ for atorvastatin and $230 \mathrm{~nm}$ for fluvastatin and pravastatin. Flow rate: $1 \mathrm{~mL} \mathrm{~min}{ }^{-1}$. Column temperature: ambient temperature. The peak area ratios were plotted against drug concentration for calibration curve construction and the regression parameters were deduced.

\section{Analysis of tablets}

Five Ator ${ }^{\circledR}$, Lescol ${ }^{\circledR}$ XL and Cholestate ${ }^{\circledR}$ tablets were grounded to a homogenous fine powder, weighed and the average mass per tablet was determined. The amount of powder 
equivalent to $10 \mathrm{mg}$ of $\mathrm{AT}$, FL and PV was transferred accurately into a $100 \mathrm{~mL}$ volumetric flask containing $70 \mathrm{~mL}$ of methanol for AT or acetonitrile -water (50:50) for FL and PV. The content of the flasks was sonicated for about five minutes and then dilutions were made using methanol. Afterwards, the solutions were filtered to separate insoluble excipients. The obtained solution labeled to contain $0.1 \mathrm{mg} \mathrm{mL}^{-1}$ of each drug was analyzed by the corresponding HPLC method as detailed under calibration.

\section{Analysis of spiked plasma}

\section{Atovastatin}

Different aliquots $(0.1-0.7 \mathrm{~mL})$ of the standard AT solution $\left(1 \mathrm{mg} \mathrm{mL} \mathrm{L}^{-1}\right)$, were added to $0.5 \mathrm{~mL}$ human plasma in a series of $10 \mathrm{~mL}$ centrifuge tube followed by $0.1 \mathrm{~mL}$ of the internal standard solution $\left(10 \mathrm{mg} \mathrm{mL}^{-1}\right) \mathrm{PR}$.

\section{Fluvastatin}

Different aliquots $(0.1-0.6 \mathrm{~mL})$ of the standard FL solution $\left(1 \mathrm{mg} \mathrm{mL}^{-1}\right)$ were added to 0.5 $\mathrm{mL}$ human plasma in a series of $10 \mathrm{~mL}$ centrifuge tube followed by $0.1 \mathrm{~mL}$ of the internal standard solution $\left(10 \mathrm{mg} \mathrm{mL}^{-1}\right) \mathrm{PR}$.

\section{Pravastatin}

Different aliquots $(0.1-0.5 \mathrm{~mL})$ of the standard PV solution $\left(2 \mathrm{mg} \mathrm{mL}^{-1}\right)$ were added to 0.5 $\mathrm{mL}$ human plasma in a series of $10 \mathrm{~mL}$ centrifuge tube followed by $0.2 \mathrm{~mL}$ of the internal standard solution $\left(10 \mathrm{mg} \mathrm{mL}^{-1}\right)$ IB.

For each drug, volume was completed to $2 \mathrm{~mL}$ with acetonitrile, then vortex for $3 \mathrm{~min}$ and centrifuged at $4000 \mathrm{rpm}$ for $30 \mathrm{~min}$. One $\mathrm{mL}$ of the clear supernatant was transferred to series of $10 \mathrm{~mL}$ volumetric flasks, completed to volume with the mobile phase to achieve the specific linearity range. The general procedure described under calibration was followed and each drug concentrations were calculated from the regression parameters.

\section{Results and Discussion}

Statins are rapidly absorbed from the gastro-intestinal tract. They have low absolute bioavailability ranging from 5 to $24 \%$ due to pre-systemic clearance in the gastro intestinal mucosa and/or first-pass metabolism in the liver, their primary site of action $^{40}$. To assess the applicability of the method for determination of statins in biological fluids, drug spiked plasma samples were analyzed by the proposed method after deproteination with acetonitrile.

\section{Optimization of chromatographic conditions}

The composition of the mobile phase was studied by trying acetonitrile and $\mathrm{KH}_{2} \mathrm{PO}_{4}\left(5 \times 10^{-2} \mathrm{M}\right)$ in different ratios using isocratic and gradient elution. The best peak shape and adequate separation of the drug and internal standard was obtained by a final composition of acetonitrile- $\mathrm{KH}_{2} \mathrm{PO}_{4}(60: 40 \mathrm{v} / \mathrm{v})$ for AT, FL and $(40: 60 \mathrm{v} / \mathrm{v})$ for PV, respectively. All mobile phase $\mathrm{pH}$ was adjusted to 3.5 by orthophosphoric acid. Different flow rates $\left(0.5-1.2 \mathrm{~mL} \mathrm{~min}^{-1}\right)$ were tested; good resolution was obtained using $1 \mathrm{~mL} / \mathrm{min}$. Four wavelengths were tried $(210,230,240$ and $280 \mathrm{~nm})$; much sensitive detector response was obtained at $210 \mathrm{~nm}$ for AT, $230 \mathrm{~nm}$ for FL and PV. System suitability parameters were calculated and the retention times were $2.4 \pm 0.05$ min for AT and $1.26 \mathrm{~min}$ for the internal standard PR (Figure 1). 
System suitability

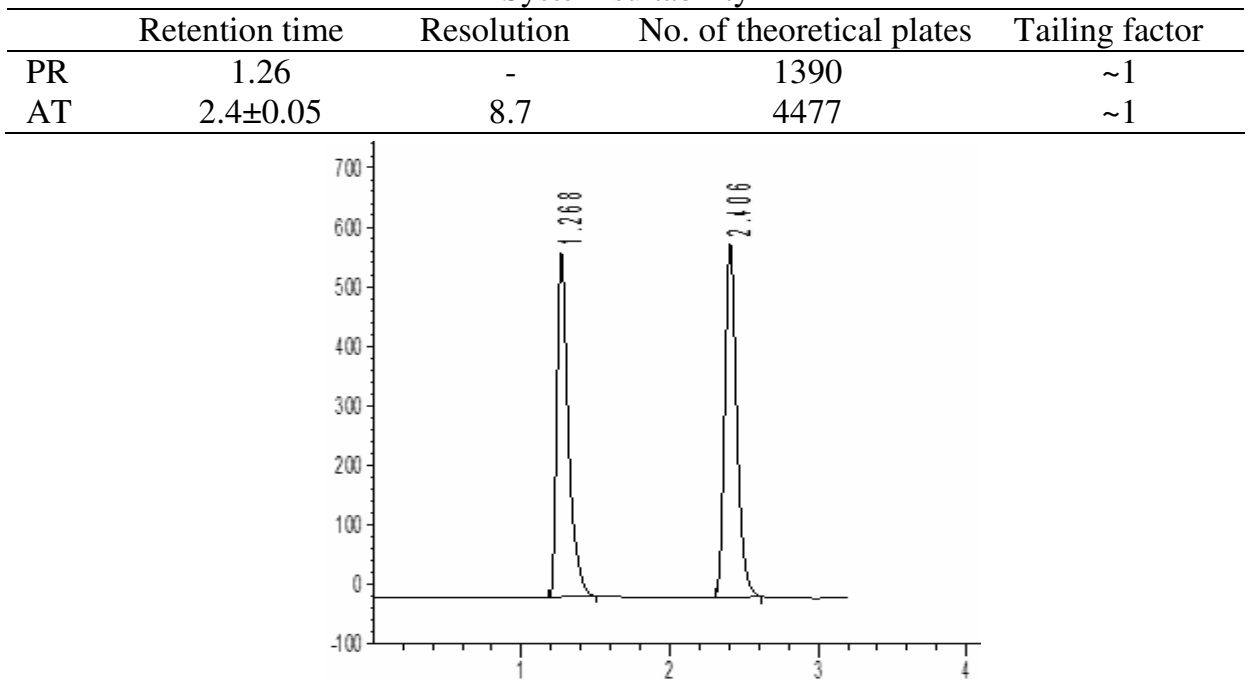

Figure 1. Chromatogram of atorvastatin calcium and internal standard pyridoxine $\mathrm{HCl}$

As shown in (Figure 2) the retention times were: $4.0 \pm 0.3 \mathrm{~min}$ for FL and 1.26 for PR. (Figure 3) shows that the retention time for PV is $1.84 \pm 0.1 \mathrm{~min}$ and $4.3 \pm 0.1 \mathrm{~min}$ for the internal standard IB.

System suitability (Figure 2)

\begin{tabular}{lcccc}
\hline & Retention time & Resolution & No. of theoretical plates & Tailing factor \\
\hline PR & 1.26 & - & 1398 & $\sim 1$ \\
FL & $4 \pm 0.3$ & 15.64 & 5865 & $\sim 1$ \\
\hline
\end{tabular}

System suitability (Figure 3)

\begin{tabular}{lcccc}
\hline & Retention time & Resolution & No. of theoretical plates & Tailing factor \\
\hline IB & $4.3 \pm 0.1$ & - & 9612 & $\sim 1$ \\
PV & $1.84 \pm 0.1$ & 16.52 & 4307 & $\sim 1$ \\
\hline
\end{tabular}
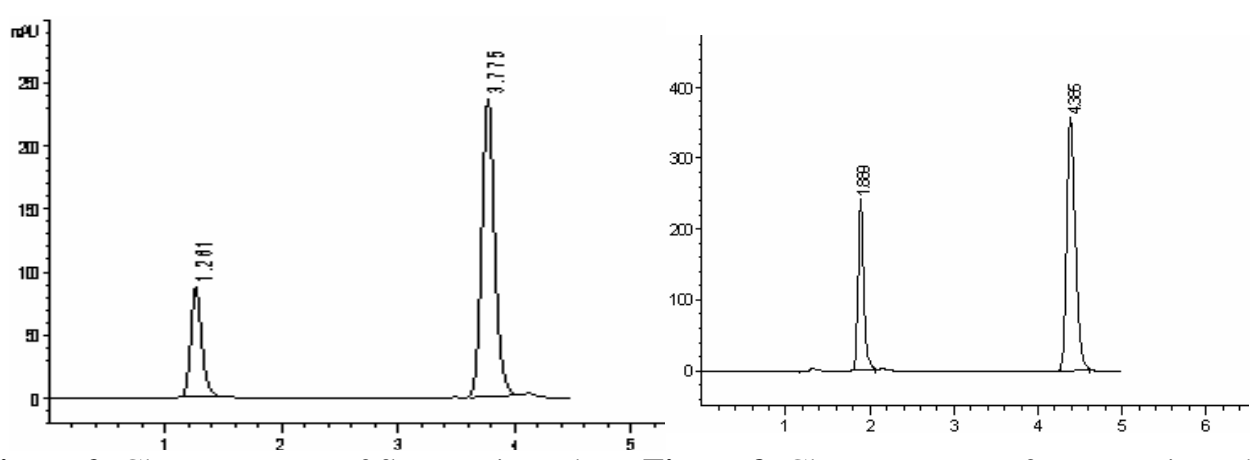

Figure 2. Chromatogram of fluvastatin and Figure 3. Chromatogram of pravastatin and internal standard pyridoxine $\mathrm{HCl}$ Method validation internal standard ipubrofen

The procedure was intended for an assay which is described as a category I procedure in General Chapter (1225) Validation of Compedial methods of US Pharmacopeia. 


\section{Linearity, detection and quantitation limits}

Calibration curves representing the relation between each drug concentrations and peak area ratio were constructed. Results show linear relationship in the range of 5-40, 5-30 and 10-60 $\mu \mathrm{gmL}^{-1}$ for atorvastatin, fluvastatin and pravastatin respectively; in triplicate run from which linear regression equations were calculated. Correlation coefficient, slope and intercept were listed in Table 1. Results indicate high sensitivity of the proposed methods.

According to ICH recommendation ${ }^{41}$, the approach based on the S.D. of the response and the slope was used for determining the detection and quantitation limits. The theoretical values were assessed practically and given in Table 1.

\section{Accuracy}

Accuracy of the measurements was determined using the calibration standards of the three drugs, where mean percentage of 100.58, 100.22 and 100.31 for AT, FL and PV, respectively, were obtained (Table 1). Accuracy was also assessed by the recovery of added standard, three concentrations each in duplicate to know concentration of commercial tablets using the proposed HPLC procedures. Results of mean \% recovery for added standards in each tablet are reported in Table 2.

\section{Precision}

\section{Injection repeatability}

The RSD of drugs peak area ratio in five triplicate injections of standard drug solution determined each day of 3 consecutive days ranged from $0.14-1.28 \%$ (Table 1).

\section{Assay repeatability}

Analysis of 3 concentrations of tablets was performed in triplicate each day of 3 successive days. Results for the intraday RSD and interday for each dosage form were recorded in Table 1 providing the high reproducibility and ruggedness of the proposed HPLC methods.

Table 1. Selected physical data for the determination of atorvastatin, fluvastatin and pravastatin by the proposed HPLC methods

\begin{tabular}{|c|c|c|c|}
\hline Parameters & AT & FL & $\mathrm{PV}$ \\
\hline Linearity range, $\mu \mathrm{g} \mathrm{mL}^{-1}$ & $5-40$ & $5-30$ & $10-60$ \\
\hline Slope \pm S.E & $0.026 \pm 9.6 \mathrm{E}-05$ & $0.049 \pm 6.54 \mathrm{E}-04$ & $0.007 \pm 4.86 \mathrm{E} 05$ \\
\hline Intercept \pm S.E. & $0.003 \pm 0.0024$ & $-0.005 \pm 0.012$ & $-0.0034 \pm 0.0018$ \\
\hline Correlation Coefficient & 0.999 & 0.999 & 0.999 \\
\hline $\begin{array}{l}\text { Accuracy } \pm \text { S.D } \\
\text { Precision }\end{array}$ & $100.58 \pm 0.48$ & $100.22 \pm 1.36$ & $100.31 \pm 1.21$ \\
\hline $\begin{array}{l}\text { Injection Repeatability } \\
\qquad(\mathrm{n}=15)\end{array}$ & $0.80-1.26$ & $0.14-0.38$ & $0.32-1.28$ \\
\hline Assay Reproducibility & Ator $®$ & Lescol $®$ XL & Cholestate ${ }^{\circledR}$ \\
\hline Intraday $(n=9)$ & $0.40-1.79 \%$ & $0.13-0.28 \%$ & $0.10-0.20 \%$ \\
\hline Interday $(n=27)$ & $\begin{array}{c}\text { Ator }{ }^{\circledR} \\
1.01 \%-1.72 \%\end{array}$ & $\begin{array}{l}\text { Lescol@ XL } \\
0.39-0.73 \%\end{array}$ & $\begin{array}{l}\text { Cholestate }{ }^{\circledR} \\
0.17-0.35 \%\end{array}$ \\
\hline $\mathrm{LOQ}^{\mathrm{a}}, \mu \mathrm{g} \mathrm{mL}^{-1}$ & 4 & 4 & 5 \\
\hline $\mathrm{LOD}^{\mathrm{a}}, \mu \mathrm{g} \mathrm{mL}^{-1}$ & 2.5 & 2 & 3 \\
\hline
\end{tabular}

\section{Specificity}

${ }^{a} L O Q$ and $L O D$ were determined practically

Retention time of the peak in the chromatogram of tablets and spiked human plasma was the same as that of standard drugs without interference from excipients, additives or biological fluid 
components. Accordingly, specificity of the HPLC methods was evaluated by its successful application to determine drugs in their tablets with mean recovery of $99.25 \pm 0.73 \%$ for Ator ${ }^{\circledR}$ tablets, $99.90 \pm 0.68$ for Lescol ${ }^{\circledR}$ XL tablets and $100.29 \pm 0.76$ for Cholestate ${ }^{\circledR}$ tablets.

A statistical comparison of the results obtained by the proposed methods and the reported or manufacturer HPLC methods is shown in Table 2. The values of the calculated ' $t$ ' and ' $F$ ' are less than the tabulated ones, which reveals that there is no significant difference with respect to accuracy and precision between the proposed, reported and manufacturer methods.

Table 2. Statistical analysis of the results obtained by applying the proposed, reported and manufacturer methods for the analysis of AT, FL and PV in their tablets

\begin{tabular}{|c|c|c|c|}
\hline Preparation & $\begin{array}{c}\text { Proposed HPLC } \\
\text { procedure }\end{array}$ & $\begin{array}{l}\text { Reported } \\
\text { procedure }\end{array}$ & $\begin{array}{c}\text { Manufacturer } \\
\text { procedure }\end{array}$ \\
\hline \multirow{3}{*}{ Ator® $20 \mathrm{mg}$} & $99.25 \pm 0.73$ & $99.57 \pm 0.55$ & - \\
\hline & $F=1.76$ & - & \\
\hline & $\mathrm{t}=1.06$ & - & \\
\hline \multirow[t]{2}{*}{ Standard addition } & $99.42 \pm 0.52^{* *}$ & & \\
\hline & $99.90 \pm 0.68$ & - & $99.88 \pm 0.55$ \\
\hline \multirow[t]{2}{*}{ Lescol $® X L$} & $\mathrm{~F}=1.52$ & - & \\
\hline & $\mathrm{t}=0.26$ & - & \\
\hline \multirow[t]{2}{*}{ Standard addition } & $99.68 \pm 0.88^{* *}$ & & \\
\hline & $100.29 \pm 0.76$ & $100.23 \pm 0.84$ & - \\
\hline \multirow[t]{3}{*}{ Cholestate ${ }^{\circledR}$} & $\mathrm{F}=1.22$ & & \\
\hline & $\mathrm{t}=0.15$ & & \\
\hline & $100.14 \pm 0.28^{* *}$ & & \\
\hline
\end{tabular}

${ }^{*}$ Mean of nine determinations (three conc. each in triplet) ${ }^{* *}$ Mean of six determinations (two for each of 10,20 and $30 \mu \mathrm{g} \mathrm{mL}$

Moreover, the proposed methods were extended to analyze drugs in spiked human plasma by simple extraction and deproteination with acetonitrile, followed by centrifugation and the clear supernatant containing the drug was adjusted to volume by the mobile phase and analyzed directly by HPLC procedures. Nearly non-destructive extraction was obtained as obvious from a mean \% recovery of 98.19 -98.87 from plasma (Table 3).

Table 3. Determination of atorvastatin, fluvastatin and pravastatin in spiked human plasma

\begin{tabular}{ccccccccc}
\hline \multicolumn{1}{c}{ AT } \\
$\begin{array}{c}\text { Spiked } \\
\text { conc. } \mu \mathrm{g} \\
\mathrm{mL}^{-1}\end{array}$ & $\begin{array}{c}\text { Found } \\
\text { conc. }^{*}\end{array}$ & $\begin{array}{c}\text { Recovery } \\
\%\end{array}$ & $\begin{array}{c}\text { Spiked } \\
\text { conc. } \\
\mu \mathrm{gmL}^{-1}\end{array}$ & $\begin{array}{c}\text { Found } \\
\text { conc }^{*}\end{array}$ & $\begin{array}{c}\text { Recovery } \\
\%\end{array}$ & $\begin{array}{c}\text { Spiked } \\
\text { conc. } \\
\mu \mathrm{g} \mathrm{mL} \mathrm{m}^{-1}\end{array}$ & $\begin{array}{c}\text { Found } \\
\text { conc. }^{*}\end{array}$ & $\begin{array}{c}\text { Recovery } \\
\%\end{array}$ \\
\hline 5 & 5.01 & 100.34 & 5 & 4.90 & 98.01 & 10 & 9.83 & 98.32 \\
10 & 9.98 & 99.81 & 10 & 9.81 & 98.10 & 20 & 19.97 & 99.85 \\
15 & 14.93 & 99.54 & 15 & 14.86 & 99.06 & 30 & 29.58 & 98.61 \\
20 & 19.84 & 99.22 & 20 & 19.72 & 98.60 & 40 & 39.72 & 99.38 \\
30 & 30.03 & 100.11 & 30 & 29.46 & 98.20 & 50 & 49.15 & 98.31 \\
\hline \multicolumn{8}{c}{ *Average of three determinations } \\
\hline
\end{tabular}

\section{Conclusion}

The proposed HPLC methods were shown to be specific, precise, linear and easy to perform allowing rapid determination of atorvastatin calcium, fluvastatin sodium pravastatin sodium in tablets and spiked human plasma. Validation of the proposed methods was carried out 
according to the ICH and USP guidelines. The short duration of the assay and its specificity were clear bonuses for routine analysis (batch analysis) and clinical application.

\section{Acknowledgment}

The author thanks EPICO, Novartis Pharma, HI Pharm pharmaceuticals and Memphis Co. for the donation of authentic drug powders and free samples of pharmaceutical preparations.

\section{References}

1. $\quad$ Endo A, J Lipid Res., 1992, 33(11), 1569-1582.

2. Stanisz B and Rafa W, Chem Anal (Warsaw,-Pol), 2008, 53, 417.

3. Nagara J, Vipul K and Rajshree M, Anal Sci., 2007, 23, 445-451.

4. Sonawane SS, Shirkhedkar AA, Fursule R A and Surana S J, Eurasian J Anal Chem., 2006, 1, 31-41.

5. $\quad$ Erk N, Anal Lett., 2003, 36, 2699-2711.

6. Skorda D and Kontoyannis C G, Talanta, 2008, 74, 1066-1070.

7. Seshachalam U and Kothapally C B, J Liq Chromatogr Relat Technol., 2008, 31, 714-721.

8. Mohammadi A, Rezanour N, Dogaheh M A, Bidkorbeh F G, Hashem M and Walker R B, J Chromatogr B Anal Technol Biomed Life Sci., 2007, 846, 215-221.

9. Altuntas T G and Erk N, J Liq Chromatogr Relat Technol., 2004, 27(1), 83-93.

10. Erturk S, Aktas E S, Ersoy L and Ficicioglu S, J Pharm Biomed Anal., 2003, 33, 1017-1023.

11. Petkovska R M, Cornett C and Dimitrovska A, Anal Lett., 2008, 41, 992-1009.

12. Jemal M, Ouyang Z, Chen B C and Teitz D, Rapid Commun Mass Spectrom., 1999, 13, 1003-1015.

13. Bullen W W, Miller R A and Hayes R N, J Am Soc Mass Spectrom., 1999, 10(1), 55-66.

14. Nirogi R, Mudigonda K and Kandikere V, J Pharm Biomed Anal., 2007, 44, 379- 387.

15. Gerber R, Ryan J D and Clark D S, Anal Biochem., 2004, 329(1), $28 .$.

16. Borek-Dohalsky V, Huclova J, Barrett B, Nemec B, Ulc I and Jelinek I, Anal Bioanal Chem., 2006, 386(2), 275-285.

17. Dhaneshwar S S, Dhaneshwar S R, Deshpande P and Patil M, Acta Chromatogr., 2007, 19, 141-148.

18. Jamshidi A and Nateghi A R, Chromatographia., 2007, 65, 763-766.

19. Erk N, Crit-Rev Anal Chem., 2004, 34, 1-7.

20. Miller J M, Blackburn A C, Shi Y, Melzak A J, and Ando H Y, Electrophoresis, 2002, 23, 2833-2841.

21. Shum Y Y, Huang N, Walter G, Black A, Sekerke C, Chang T and Whitfield L R, Ther Drug Monit., 1998, 20(1), 41-49.

22. Erk N, Pharmazie, 2002, 57(12), 817-819.

23. Nakashima A, Saxer C, Niina M, Masuda N, Iwasaki K and Furukawa K, $J$ Chromatogr B Biomed Sci Appl., 2001, 760, 17.

24. Toreson H and Eriksson B M, J Chromatogr A., 1996, 729(1-2), 13-18.

25. Kalafsky G, Smith H T and Choc M G, J Chromatogr Biomed Appl., 1993, 125, 307.

26. Leis H and Windischhofer W, Rapid Commun Mass Spectrom., 2005, 19, 128.

27. Ozkan S A and Uslu B, Anal Bioanal Chem., 2002, 372(4), 582-586.

28. Dogrukol A K, Kircali K, Tuncel M and Aboul-Enein H Y, Biomed Chromatogr., 2001, 15, 389-392. 
29. Campos-Lara M and Mendoza-Espinoza J A, J Liq Chromatogr Relat Technol., 2008, 31, 619-623.

30. Bauer S, Mwinyi J, Stoeckle A, Gerloff T and Roots I, J Chromatogr B Anal Technol Biomed Life Sci., 2005, 818, 257-262.

31. Iacona I, Regazzi M, Buggia I, Villani I, Fiorito V, Molinaro M and Guarnone E, Ther Drug Monit 1994, 16, 191-195.

32. Otter K and Mignat C, J Chromatogr B Biomed Sci Appl., 1998, 708, 235-241.

33. Whigan DB, Ivashkiv E and Cohen A I, J Pharm Biomed Anal., 1989, 7(7), 907-912.

34. Zhu Z M and Neirinck L, J Chromatogr B Anal Technol Biomed Life Sci., 2003, 783, 133.

35. Mulvana D, Jemal M and Coates-Pulver S, J Pharm Biomed Anal., 2000, 23, 851-866.

36. Iwabuchi H, Kitazawa E, Kobayashi N, Watanabe H, Kanai M, Nakamura K, Biol Mass Spectrom., 1994, 23, 540-546.

37. Lenz E M, Williams R E, Sidaway J, Smith B W, Plumb R S, Johnson K A, Rainville P, Shockcor J, Stumpf C L, Granger J H and Wilson I D, J Pharm Biomed Anal., 2007, 44, 845-852.

38. Nigovic B, Anal Bioanal Chem., 2006, 384, 431.

39. Coskun N Y, Aycan S and Sungur S, Die-Pharmazie., 1997, 52, 485.

40. Khathleen P, Martindale, The Complete Drug Reference, 32 ${ }^{\text {nd }}$ Edition, $(\mathrm{PhP})$ Pharmaceutical press, 1 Lambeth High Street, London, UK, 1999,1268.

41. The European Agency for the Evaluation of Medical Products, ICH Topic Q2B Note for Guidance on Validation of Analytical Procedures; Methodology GPMP/ ICH/ 1995, 28. 


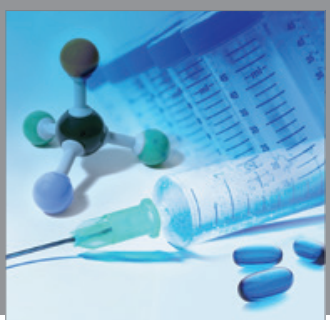

International Journal of

Medicinal Chemistry

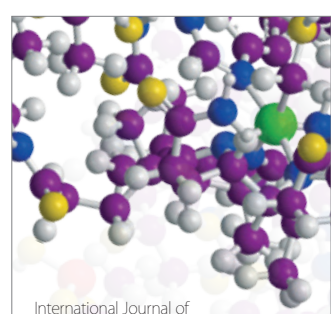

Carbohydrate Chemistry

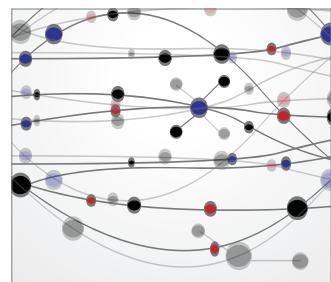

The Scientific World Journal
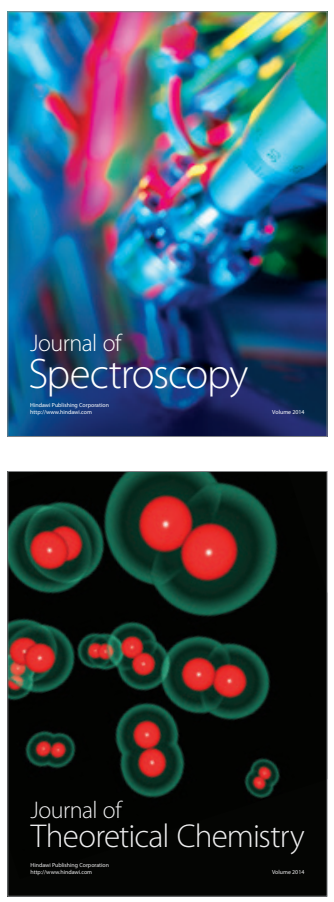
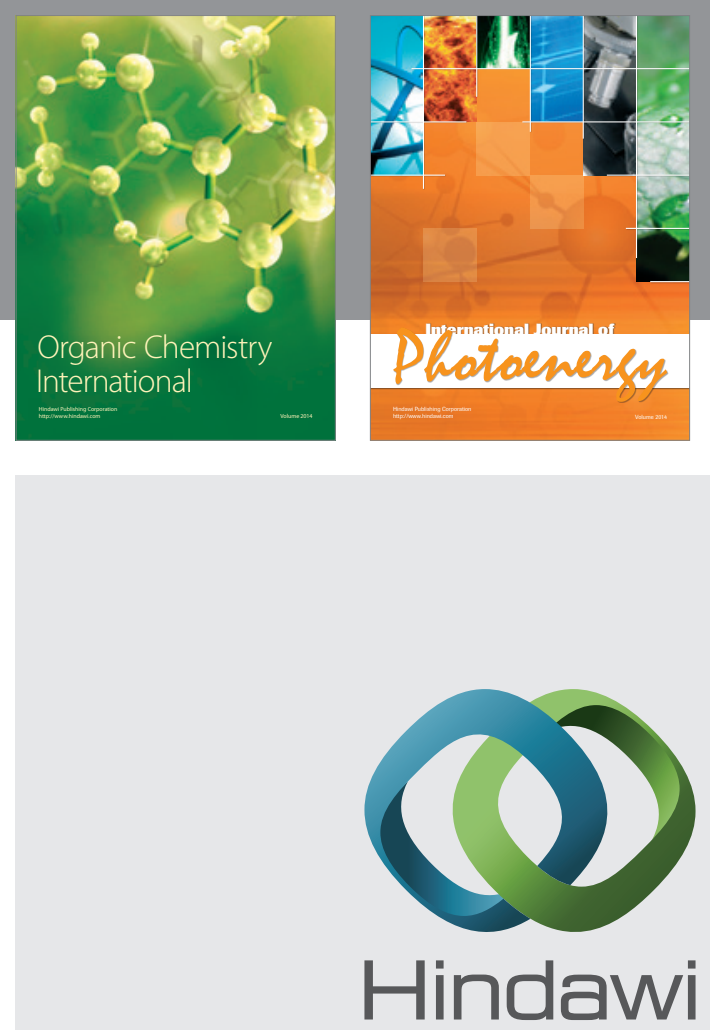

Submit your manuscripts at

http://www.hindawi.com
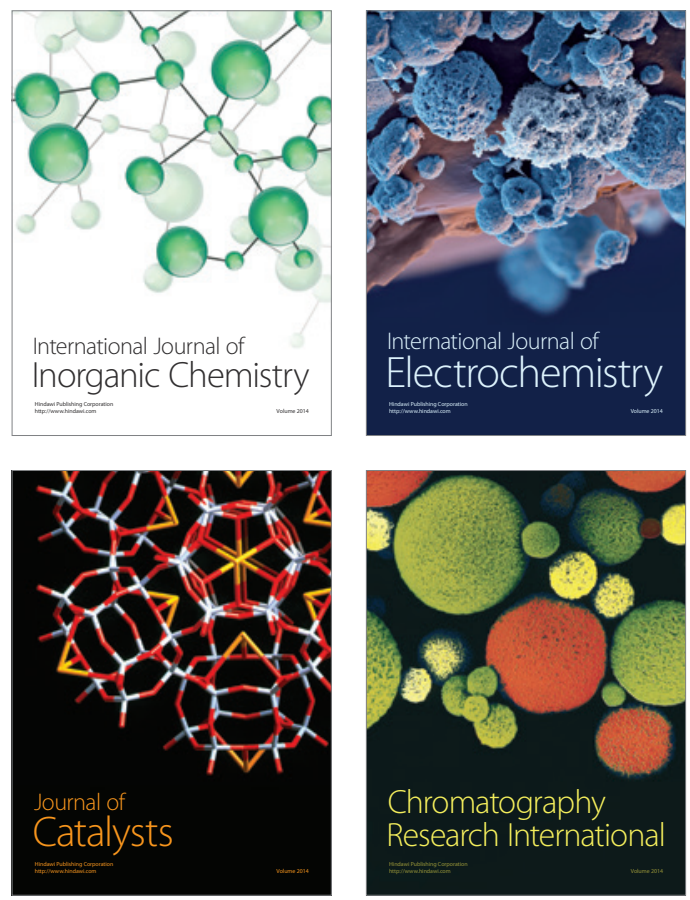
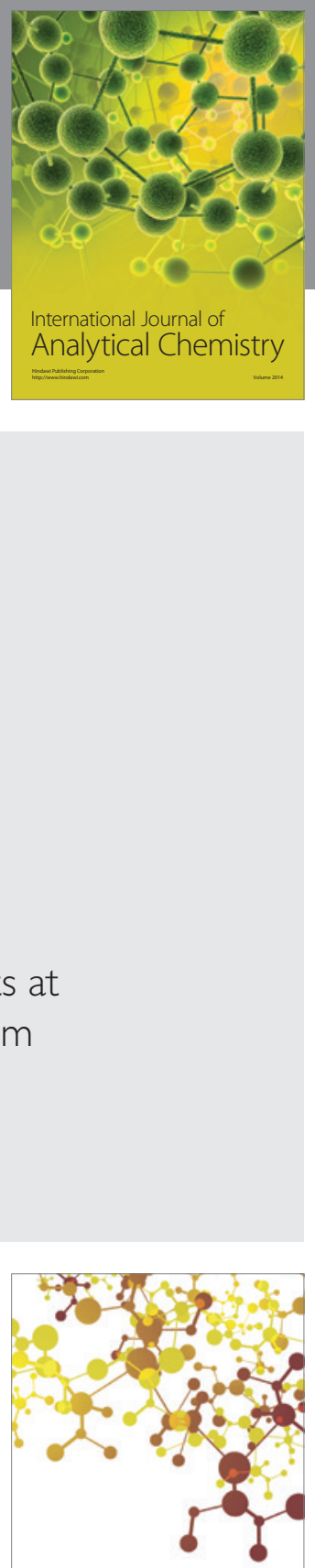

Journal of

Applied Chemistry
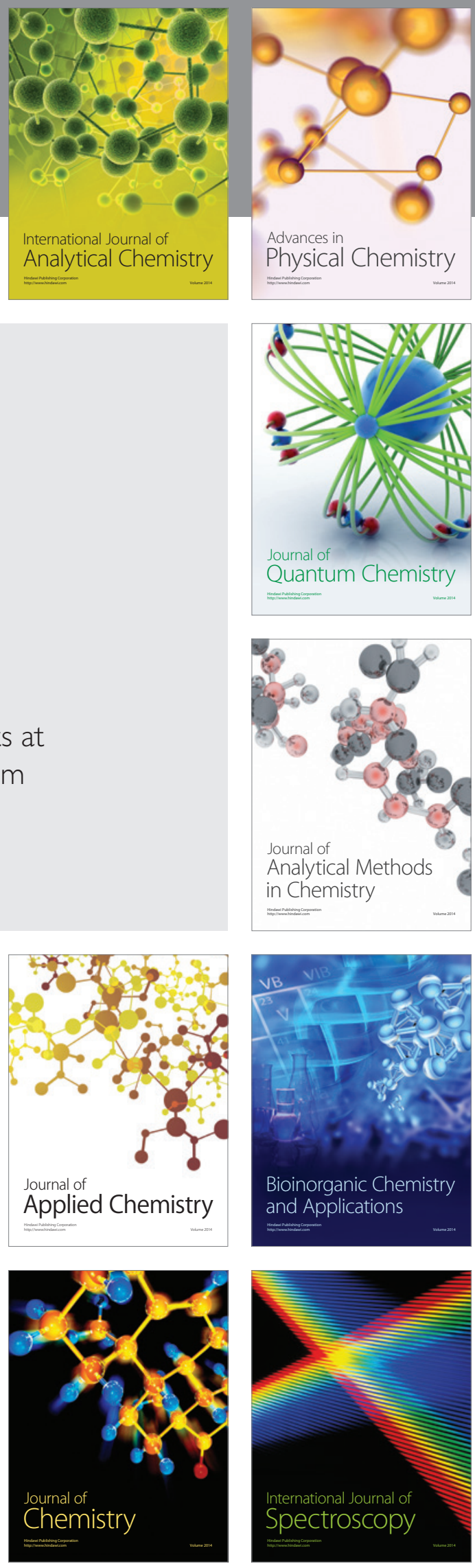